\title{
Composition and mineralization of organic compost derived from composting of fruit and vegetable waste ${ }^{1}$
}

\author{
Mauricio Vicente Motta Tratsch ${ }^{2 *}$ (D), Carlos Alberto Ceretta ${ }^{3}$, Leandro Souza da Silva ${ }^{3}$, \\ Paulo Ademar Avelar Ferreira ${ }^{3}$, Gustavo Brunetto ${ }^{3}$
}

10.1590/0034-737X201966040009

\begin{abstract}
Fruit and vegetable waste can be used for the production of organic compost, which when mineralized can increase the availability of nitrogen. The objectives of this study were: (a) to produce compost from different ratios of fruit and vegetable waste, rice husk and poultry manure that meets the legislation on organic fertilizers and (b) to assess the mineralization of $\mathrm{N}$ in substrates prepared with different ratios of compost. In experiment 1, the following treatments were prepared using (fruit and vegetable residue: rice husk: poultry waste) (v:v): Treatment 1 (2:1:0), T2 (1:1:1), T3 (1.5:1:0) and T4 (1.2:1:0). All the treatments were subjected to composting for 95 days, were subjected to analysis of nutrients, organic carbon, $\mathrm{C} / \mathrm{N}, \mathrm{CEC} / \mathrm{C}, \mathrm{pH}$ and moisture content. The composts were compared in regards to the parameters required by legislation. In experiment 2, the treatments consisted of eight blends of agricultural peat, carbonized rice husk and organic compost pre-selected from experiment 1 . The $\mathrm{NO}_{3}-\mathrm{N}^{-}$and $\mathrm{NH}_{4}^{+}{ }_{4}-\mathrm{N}$ contents were analyzed in the substrate at time zero and at 7, 14, 28, 56, 112 days after incubation. Compost (C2) met the parameters required by legislation and the use of $40 \%$ in the substrate composition promoted the mineralization of $\mathrm{N}$.
\end{abstract}

Keywords: organic fertilizer; nutrientes; substrates.

\section{INTRODUCTION}

In Brazil, 30 to $40 \%$ of foods such as vegetables and fruits are lost on the way from the producer to the consumer (Souza et al., 2011). Of this total, $54 \%$ of the losses occur in the phases of production, handling, post-harvest and storage. In general, $11 \%$ of the food stored in places such as supermarkets is wasted, representing an average loss of $2.93 \%$ in revenue (ABRAS, 2015). However, as the Brazilian decree law no. 2848 of 1940 prevents food leftovers from being donated, fruit and vegetable waste can be used in composting.

Composting is an aerobic process of biological transformation of organic waste under controlled conditions, which provides the development of biological activity (Bueno et al., 2008; Dores et al., 2013). The composting process is flexible and can be done in an open or in a closed system. In the open system, the organic material is piled in heaps, which are turned at time intervals to promote aeration of the medium. The closed system involves the use of reactors, which allow better control of the aeration conditions, temperature and moisture, but the costs are higher (Hubbe et al., 2010).

In composting, the temperature oscilates over time and it is possible to define three phases in terms of biological activity: mesophilic, thermophilic and the maturation. These phases are not static, having transition points and variability depending on the moisture conditions, oxygen level and amount of waste (Andreoli, 2011).

Brazilian legislation requires that a composite fertilizer, such as organic compost, has the following minimum

\footnotetext{
Submitted on April 29th, 2019 and accepted on August 07th 2019.

${ }^{1}$ This work is part of the doctoral thesis of the first author.

${ }^{2}$ Universidade Federal de Santa Maria, Colégio Politécnico, Santa Maria, Rio Grande do Sul, Brazil. mauriciotratsch@yahoo.com.br

${ }^{3}$ Universidade Federal de Santa Maria, Departamento de Solos, Santa Maria, Rio Grande do Sul, Brazil. carlosceretta@gmail.com; leandrosolos@ufsm.br; ferreira.aap@gmail.com; gustavo.brunetto@gmail.com

* Corresponding author: mauriciotratsch@yahoo.com.br
} 
parameters in order to be commercialized: TOC $(>15 \%)$, total $\mathrm{N}$ (minimum of $1 \%$ ), moisture (maximum of $50 \%$ ), $\mathrm{C} / \mathrm{N}$ ratio (maximum of 20:1) and $\mathrm{pH}$ (minimum of 6.0) (BRASIL (2009).

To produce an organic compost that meets these characteristics, it is necessary to understand its composition (fruit and vegetable waste, rice husk and poultry manure), as well as to establish a mixture ratio that favors the activity of decomposing microorganisms, while at the same time avoiding possible losses during the process that lead to undesirable parameters caused by excess or lack of moisture and nutrients, producing unpleasant sulphide or ammoniac odors and slurry formation (Costa et al., 2009).

Organic compost derived from different mixtures of waste can be used as a source of nutrients for crops, especially perennial crops, such as fruit trees, because they can release nutrients, such as $\mathrm{N}$, more gradually, increasing nutrient use by plants, and consequently reducing loss to the environment (Morais \& Maia, 2013).

Therefore, he study aimed to: a) evaluate the chemical parameters of maturation and the quality requirements demanded by legislation in four composts produced with different ratios of mixtures of fruit and vegetable waste, rice husk and poultry manure and $b$ ) verify the dynamics of $\mathrm{N}$ release in the substrates produced from different ratios of mixtures of organic compost, agricultural peat and carbonized rice husk.

\section{MATERIALAND METHODS}

\section{Experiment 1 - Composition of the organic composts}

The composting was conducted inside an organic waste treatment facility of the Universidade Federal de Santa Maria (UFSM), located in the city of Santa Maria (RS), Brazil. The facilty had metal roofing with sheets formed by an alloy coating of 55\% of aluminum, $43.4 \%$ of zinc and $1.6 \%$ of silicon; a concrete floor sloping from the sides towards the center, where a drain was located to collect the slurry.

The materials used in the composition of the treatments were fruit and vegetable waste (FVW) from a supermarket chain, collected and stored in water tanks until reaching the volume required for the application of the weekly doses; rice husk $(\mathrm{RH})$ from a grain processing business; and poultry manure (PM) from birds raised in suspended cages. The samples of organic waste were collected, crushed and dried in an oven with forced air at $65^{\circ} \mathrm{C}$ until constant weight; ground and subjected to chemical analysis Tedesco et al. (1995) (Table 1).

Initially, a base mixture (v:v) of $60 \% \mathrm{FVW}$ and $40 \%$ rice husk $(\mathrm{RH})$ was used for the preparation of the

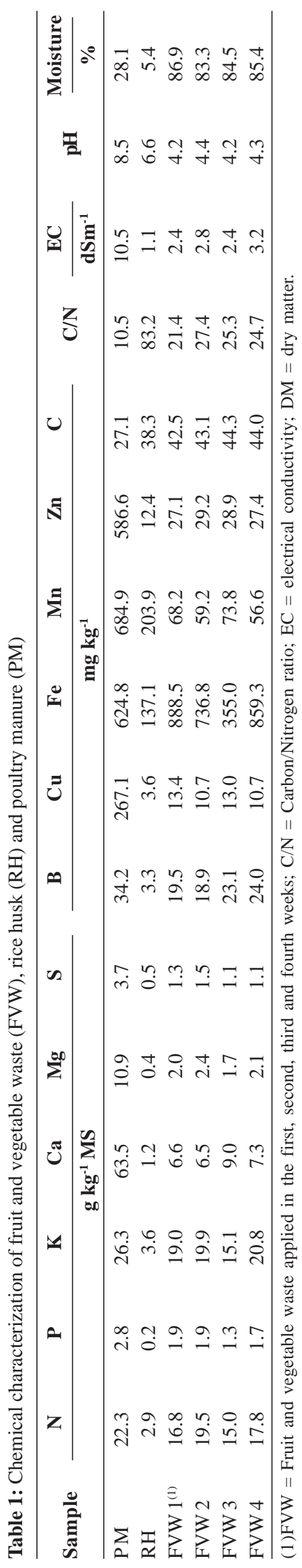


treatments. The amounts used for the mixing of these wastes were defined from preliminary studies to obtain a moisture content of approximately $55 \%$, ideal for the beginning of the composting process (Kiehl, 2010). This base mixture was used to prepare the treatments (piles). During the next three weeks, new additions of FVW (treatments 1, 3 and 4) and FVW + PM (treatment 2) were made, as shown in (Table 2).

The compost piles of each treatment were $3.0 \mathrm{~m}$ long, $1.0 \mathrm{~m}$ wide and $1.0 \mathrm{~m}$ high. Each pile was divided into three portions of $1.0 \mathrm{~m}$ in length, comprising the replicates. The turning of the compost was done manually with a shovel and hoe every three days during the first 30 days. After 30 days the turning was done weekly until the stabilization of the temperature at 95 days. The composting process was carried out for 95 days from November 2, 2015 to February 4, 2016.

Throughout the composting period, the temperature was measured at $20 \mathrm{~cm}$ from the surface and at $20 \mathrm{~cm}$ from the base of the treatment, on a daily basis and before the waste was turned. At the end of the 95 days of composting, with the stabilization of the temperature, each treatment produced organic compost (C1, C2, C3 and C4).

Three samples were collected randomly from each compost. The samples were dried in an oven with forced air at $65{ }^{\circ} \mathrm{C}$ to constant weight. The samples were ground and prepared for analysis of total contents of total organic carbon (TOC) and nitrogen in a CHNS analyzer (Thermo Finnigan FlashEA 1112 Series, Milan, Italy); pH, moisture content, and total contents of $\mathrm{P}, \mathrm{K}, \mathrm{Ca}, \mathrm{Mg}, \mathrm{S}, \mathrm{B}, \mathrm{Cu}, \mathrm{Fe}$, $\mathrm{Mn}, \mathrm{Zn}, \mathrm{NH}_{4}^{+}-\mathrm{N}$ and $\mathrm{NO}_{3}^{-}-\mathrm{N}$, according to the methodology proposed by Tedesco et al. (1995).

\section{Experiment 2 - $N$ mineralization of the organic composts in substrate}

The experiment was conducted in a laboratory at the Universidade Federal de Santa Maria (UFSM), in Santa Maria (RS), in April 2016. We collected samples of agricultural peat (AP), carbonized rice husk (CRH) and organic compost $\mathrm{C} 2$ produced in experiment 1 by mixing FVW+PM+RH (Table 3).

The compost chosen for this experiment presented the best values as regards the parameters established by legislation (BRASIL (2009)). The organic compost had the following characteristics on a dry basis: $9.09 \mathrm{pH} ; 179.19$ $\mathrm{mg} \mathrm{kg}^{-1} \mathrm{NH}_{4}^{+}-\mathrm{N} ; 432.79 \mathrm{mg} \mathrm{kg}^{-1} \mathrm{NO}_{3}^{-}-\mathrm{N}, 1.51 \%$ total $\mathrm{N}(\mathrm{Nt})$; $0.41 \%$ total $\mathrm{P} ; 2.99 \%$ total $\mathrm{K} ; 4.83 \%$ total $\mathrm{Ca} ; 0.83 \%$ total $\mathrm{Mg}, 0.37 \%$ total $\mathrm{S}, 0.003 \%$ total B, $0.018 \%$ total $\mathrm{Cu}, 0.6 \%$ total Fe, $0.065 \%$ total $\mathrm{Mn}, 0.044 \%$ total $\mathrm{Zn}, 24.19 \%$ TOC and $15.95 \mathrm{C} / \mathrm{N}$ ratio.

The treatments consisted of the mixture of AP, CHR and $\mathrm{C} 2: 40 \% \mathrm{AP}+60 \% \mathrm{CRH}$ (control), $20 \% \mathrm{AP}+80 \%$ $\mathrm{C} 2,30 \% \mathrm{AP}+70 \% \mathrm{C} 2,40 \% \mathrm{AP}+60 \% \mathrm{C} 2,50 \% \mathrm{AP}+50 \%$ $\mathrm{C} 2,60 \% \mathrm{AP}+40 \% \mathrm{C} 2,70 \% \mathrm{AP}+30 \% \mathrm{C} 2$ and $80 \% \mathrm{AP}+$ $20 \%$ C2. The experimental design was completely randomized with four replicates. The chemical characteristics of the treatments prior to incubation are shown in (Table 4).

Table 2: Amounts and ratios of fruit and vegetable waste (FVW), rice husk (RH) and poultry manure (PM) added on a weekly basis

\begin{tabular}{|c|c|c|c|c|c|c|c|c|c|}
\hline & \multicolumn{2}{|c|}{ Treatment 1} & \multicolumn{3}{|c|}{ Treatment 2} & \multicolumn{2}{|c|}{ Treatment 3} & \multicolumn{2}{|c|}{ Treatment 4} \\
\hline & FVW & RH & FVW & RH & PM & FVW & RH & FVW & RH \\
\hline Base mixture (kg) & 378 & 63 & 189 & 63 & 156 & 378 & 63 & 378 & 63 \\
\hline Week 1 (kg) & 252 & na & 126 & na & 104 & 252 & na & 252 & na \\
\hline Week $2(\mathrm{~kg})$ & 252 & na & 126 & na & 104 & 252 & na & na & na \\
\hline Week 3 (kg) & 252 & na & 126 & na & 104 & na & na & na & na \\
\hline Total (kg) & 1134 & 63 & 567 & 63 & 468 & 882 & 63 & 630 & 63 \\
\hline Ratio (m:m) & \multicolumn{2}{|c|}{$18: 1$} & \multicolumn{3}{|c|}{$9: 7.5: 1$} & \multicolumn{2}{|c|}{$14: 1$} & \multicolumn{2}{|c|}{ 10:1 } \\
\hline Ratio (v:v) & \multicolumn{2}{|c|}{$2: 1$} & \multicolumn{3}{|c|}{$1: 1: 1$} & \multicolumn{2}{|c|}{$1.5: 1$} & \multicolumn{2}{|c|}{$11.2: 1$} \\
\hline $\mathrm{C} / \mathrm{N}$ ratio & \multicolumn{2}{|c|}{25.49} & \multicolumn{3}{|c|}{27.13} & \multicolumn{2}{|c|}{25.78} & \multicolumn{2}{|c|}{126.06} \\
\hline
\end{tabular}

na $=$ not added

Table 3: Chemical characterization of the organic compost (C), agricultural peat (AP) and carbonized rice husk (CRH)

\begin{tabular}{|c|c|c|c|c|c|c|}
\hline \multirow{2}{*}{ Sample } & \multirow{2}{*}{$\begin{array}{c}\mathrm{pH} \\
\mathrm{H}_{2} \mathrm{O}(\mathbf{1 : 5})\end{array}$} & \multirow{2}{*}{$\begin{array}{c}\mathrm{EC} \\
\left(\mathrm{dSm}^{-1}\right)\end{array}$} & \multirow{2}{*}{$\frac{\mathrm{CEC}}{\left(\mathrm{mmol}_{\mathrm{c}} \mathrm{kg}^{-1}\right)}$} & $\mathbf{N}$ & TOC & \multirow{2}{*}{$\mathrm{C} / \mathrm{N}$} \\
\hline & & & & \multicolumn{2}{|c|}{ (\% dry matter) } & \\
\hline $\mathrm{C} 2$ & 8.55 & 6.76 & 303.75 & 1.51 & 24.19 & 15.95 \\
\hline AP & 5.01 & 2.24 & 1040 & 1.98 & 40.43 & 20.45 \\
\hline $\mathrm{CRH}$ & 7.25 & 0.53 & 65 & 0.73 & 44.03 & 60.25 \\
\hline
\end{tabular}

$\mathrm{pH}=$ potential of hydrogen, $\mathrm{EC}=$ electrical conductivity, $\mathrm{CEC}=$ cation exchange capacity, $\mathrm{N}=$ nitrogen, TOC = total organic carbon, $\mathrm{C} /$ $\mathrm{N}=$ Carbon/Nitrogen ratio. 
The treatments were placed in $110 \mathrm{ml}$ acrylic flasks (5 $\mathrm{cm}$ in height and $5 \mathrm{~cm}$ in diameter). The addition was done in two steps. First, the treatments were added and compacted to a height of $2.5 \mathrm{~cm}$ from the top of each acrylic flask. Afterwards, the flask was filled up to $5 \mathrm{~cm}$. The field capacity in each treatment was maintained at $70 \%$ through the addition of distilled water.

The replicates of each treatment, without the lid, were placed in $1500 \mathrm{ml}$ glass jars. The glass jars were hermetically sealed and placed in a dark incubator chamber with controlled temperature $\left(25 \pm 1{ }^{\circ} \mathrm{C}\right)$. The glass jars were opened weekly for 15 minutes to promote gas exchange and prevent possible oxygen deficiency.
Moisture was monitored by weighing the experimental units. At 0, 7, 14, 28, 56 and 112 days after incubation (DAI), the substrate was removed from the acrylic flasks, and then homogenized and prepared for the analysis of $\mathrm{NH}_{4}{ }^{+}-\mathrm{N}$ and $\mathrm{NO}_{3}{ }^{-} \mathrm{N}$ contents, according to the methodology proposed by Tedesco et al. (1995).

\section{Calculations and statistical analysis}

With the values of $\mathrm{NH}_{4}{ }^{+}-\mathrm{N}$ and $\mathrm{NO}_{3}{ }^{-} \mathrm{N}$ obtained in experiment 2 , the mineral $\mathrm{N}$ (Nmin) values were calculated according to Equation 1:

$\mathrm{Nmin}=\mathrm{NH}_{4}+\mathrm{NO}_{3}$

Table 4: Chemical characteristics of the treatments prior to incubation

\begin{tabular}{|c|c|c|c|c|c|c|}
\hline \multirow{2}{*}{ Treatments } & Nt & TOC & \multirow{2}{*}{$\mathbf{C} / \mathbf{N}$} & CEC & EC & \multirow{2}{*}{ pH } \\
\hline & \multicolumn{2}{|c|}{$(\% \mathrm{DM})$} & & $\left(\mathrm{mmol}_{\mathrm{c}} \mathrm{kg}^{-1}\right)$ & $\left(\mathrm{dSm}^{-1}\right)$ & \\
\hline $40 \% \mathrm{AP}+60 \% \mathrm{CRH}$ & 1.28 & 32.34 & 25.27 & 550 & 0.68 & 5.53 \\
\hline $20 \% \mathrm{AP}+80 \% \mathrm{C} 2$ & 1.72 & 16.74 & 9.73 & 590 & 5.25 & 6.13 \\
\hline $30 \% \mathrm{AP}+70 \% \mathrm{C} 2$ & 1.73 & 17.38 & 10.05 & 657.5 & 5.22 & 6.35 \\
\hline $40 \% \mathrm{AP}+60 \% \mathrm{C} 2$ & 1.79 & 17.77 & 9.93 & 715 & 5.08 & 6.40 \\
\hline $50 \% \mathrm{AP}+50 \% \mathrm{C} 2$ & 1.85 & 19.57 & 10.58 & 787.5 & 4.94 & 7.16 \\
\hline $60 \% \mathrm{AP}+40 \% \mathrm{C} 2$ & 1.86 & 18.63 & 9.96 & 902.5 & 4.23 & 7.03 \\
\hline $70 \% \mathrm{AP}+30 \% \mathrm{C} 2$ & 1.88 & 21.15 & 11.25 & 985 & 3.60 & 6.92 \\
\hline $80 \% \mathrm{AP}+20 \% \mathrm{C} 2$ & 1.92 & 20.73 & 10.80 & 1072.5 & 2.80 & 5.83 \\
\hline
\end{tabular}

$\mathrm{AP}=$ agricultural peat $\mathrm{CRH}=$ carbonized rice husk; $\mathrm{TOC}=$ total organic carbon; $\mathrm{EC}=$ electrical conductivity; $\mathrm{CEC}=$ cation exchange capacity; $\mathrm{Nt}=$ Total nitrogen; $\mathrm{C} / \mathrm{N}=$ Carbon/Nitrogen ratio, $\mathrm{DM}=$ dry matter.

Table 5: Chemical characteristics of organic composts 1, 2, 3 and 4 (C1, C2, C3 and C4)

\begin{tabular}{|c|c|c|c|c|c|}
\hline Variable & C1 & $\mathrm{C2}$ & C3 & $\mathrm{C4}$ & $\mathbf{P}^{2}$ \\
\hline TOC (\%DM) & $30.55 c^{1}$ & $24.19 \mathrm{~d}$ & $34.79 \mathrm{a}$ & $32.98 \mathrm{~b}$ & $>15$ \\
\hline $\mathrm{N}(\% \mathrm{DS})$ & $1.46 \mathrm{~b}$ & $1.51 \mathrm{~b}$ & $1.67 \mathrm{a}$ & $1.10 \mathrm{c}$ & $>0.5$ \\
\hline $\mathrm{C} / \mathrm{N}$ & $20.82 \mathrm{~b}$ & $15.95 \mathrm{c}$ & $20.81 \mathrm{~b}$ & $29.96 \mathrm{a}$ & $<20$ \\
\hline $\mathrm{NH}_{4}^{+}-\mathrm{N}\left(\mathrm{mg} \mathrm{kg}^{-1}\right)$ & $62.53 \mathrm{~b}$ & $179.19 \mathrm{a}$ & $53.19 \mathrm{~b}$ & $39.19 \mathrm{~b}$ & - \\
\hline $\mathrm{NO}_{3}^{-}-\mathrm{N}\left(\mathrm{mg} \mathrm{kg}^{-1}\right)$ & $202.13 \mathrm{~b}$ & $432.79 \mathrm{a}$ & $126.39 \mathrm{c}$ & $106.93 \mathrm{~d}$ & - \\
\hline $\operatorname{Nmin}\left(\mathrm{mg} \mathrm{kg}^{-1}\right)$ & $264.66 \mathrm{~b}$ & $611.98 \mathrm{a}$ & $179.58 \mathrm{c}$ & $146.12 \mathrm{~d}$ & - \\
\hline $\mathrm{P}(\% \mathrm{DM})$ & $0.19 \mathrm{c}$ & $0.41 \mathrm{a}$ & $0.22 \mathrm{~b}$ & $0.23 \mathrm{~b}$ & - \\
\hline $\mathrm{K}(\% \mathrm{DM})$ & $2.21 \mathrm{~b}$ & $2.99 \mathrm{a}$ & $1.94 \mathrm{c}$ & $1.75 \mathrm{~d}$ & - \\
\hline $\mathrm{Ca}(\% \mathrm{DM})$ & $1.15 \mathrm{~b}$ & $4.83 \mathrm{a}$ & $1.07 \mathrm{~b}$ & $0.82 \mathrm{c}$ & $>1$ \\
\hline $\mathrm{Mg}(\% \mathrm{DM})$ & $0.33 \mathrm{~b}$ & $0.83 \mathrm{a}$ & $0.23 \mathrm{c}$ & $0.23 \mathrm{c}$ & $>1$ \\
\hline $\mathrm{S}(\% \mathrm{DM})$ & $0.24 \mathrm{~b}$ & $0.37 \mathrm{a}$ & $0.19 \mathrm{c}$ & $0.13 \mathrm{c}$ & $>1$ \\
\hline $\mathrm{B}(\% \mathrm{DM})$ & $0.003 \mathrm{a}$ & $0.003 \mathrm{a}$ & $0.004 \mathrm{a}$ & $0.002 \mathrm{a}$ & $>0.03$ \\
\hline $\mathrm{Cu}(\% \mathrm{DM})$ & $0.002 \mathrm{~b}$ & $0.018 \mathrm{a}$ & $0.007 \mathrm{~b}$ & $0.002 \mathrm{~b}$ & $>0.05$ \\
\hline $\mathrm{Fe}(\% \mathrm{DM})$ & $0.26 \mathrm{~b}$ & $0.60 \mathrm{a}$ & $0.22 \mathrm{c}$ & $0.28 \mathrm{~b}$ & $>0.2$ \\
\hline $\mathrm{Mn}(\% \mathrm{DM})$ & $0.029 \mathrm{~b}$ & $0.065 \mathrm{a}$ & $0.024 \mathrm{c}$ & $0.033 \mathrm{~b}$ & $>0.05$ \\
\hline $\mathrm{Zn}(\% \mathrm{DM})$ & $0.006 \mathrm{~b}$ & $0.044 \mathrm{a}$ & $0.006 \mathrm{~b}$ & $0.004 \mathrm{~b}$ & $>0.2$ \\
\hline $\mathrm{CEC}\left(\mathrm{mmol} \mathrm{kg}^{-1}\right)$ & $303.75 \mathrm{~b}$ & $406.25 \mathrm{a}$ & $298.75 \mathrm{~b}$ & $78.08 \mathrm{c}$ & - \\
\hline $\mathrm{CEC} / \mathrm{C}$ & $14.59 \mathrm{~b}$ & $25.47 \mathrm{a}$ & $8.59 \mathrm{c}$ & $2.36 \mathrm{~d}$ & $>20$ \\
\hline $\mathrm{EC}\left(\mathrm{dSm}^{-1}\right)$ & $5.68 \mathrm{~b}$ & $11.66 \mathrm{a}$ & $4.94 \mathrm{c}$ & $3.28 \mathrm{~d}$ & - \\
\hline $\mathrm{pH}$ & $9.09 \mathrm{a}$ & $8.55 \mathrm{c}$ & $8.83 \mathrm{~b}$ & $9.00 \mathrm{a}$ & $>6.0$ \\
\hline Moisture (\%) & $55.01 \mathrm{~b}$ & $45.34 \mathrm{~d}$ & $58.34 \mathrm{a}$ & $51.17 \mathrm{c}$ & $<50$ \\
\hline
\end{tabular}

Means followed by same letter in the line do not differ by the Scott-Knott test $(\mathrm{P}<0.05)$. ${ }^{(2)} \mathrm{P}=\mathrm{Parameters}$ required by legislation (BRASIL, Instrução Normativa MAPA nº 25, 2009) 
The mineralized $\mathrm{N}$ was calculated in relation to the total nitrogen added (\% Nmin) using Equation 2:

$\% \min =\left(\frac{N \min }{N t}\right) \times 100$

The results obtained in both experiments were subjected to analysis of variance and when significant the means were compared by the Scott-Knott test ( $\mathrm{p}<$ 0.05) using SISVAR software Ferreira (2008).

\section{RESULTS AND DISCUSSION}

Experiment 1: The averages of the temperatures measured daily in the treatments (1, 3 and 4 ) for 95 days of composting were similar, and reached a temperature range between 50 and $70{ }^{\circ} \mathrm{C}$ (thermophilic phase) at 15 days after the start of composting (DASC) and maintaining these temperatures up to 40 (treatment 4 ) and 58 DASC (treatments 1 and 3) (Figure 1).

After 60 DASC, there was a decrease in temperature in all the treatments, which characterizes the return to the mesophilic phase of the process (Sivakumar et al., 2008). A more pronounced increase in temperatures in a shorter period of time was observed in treatment 2 , reaching a temperature of $55^{\circ} \mathrm{C}$ in only 3 DASC and remaining in the range of $50-70{ }^{\circ} \mathrm{C}$ up to $58 \mathrm{DASC}$. The rapid increase in temperature of treatment 2 in the first 3 DASC can be attributed to the high respiratory activity of the microbial population, favored by the greater contribution of $\mathrm{C}$, energy, nutrients and diverse microorganisms provided through PM (Table 1) (Costa et al., 2009).
In the first phase of composting, the presence of thermophilic bacteria and other organisms can cause the temperature to reach values higher than $60^{\circ} \mathrm{C}$ (Corrêa et al., 2012). These results corroborate with those obtained by Yang (2013), who found in the composting of food waste a rapid increase in temperature in $3 \mathrm{DASC}$, reaching the thermophilic phase (temperature $>55^{\circ} \mathrm{C}$ ).

After 58 DASC, all the treatments exhibited temperatures close to $40{ }^{\circ} \mathrm{C}$, which decreased over time (Figure 1). The behavior observed in the temperature curves followed the same kinetics typically found in classic composting (Zibilske \& Materon, 2015). At 95 DASC, the treatments exhibited temperatures close to those of room temperature, showing that the lack of the addition of FVW promoted a gradual reduction in the availability of labile $\mathrm{C}$, energy and nutrients to the microbial population, reducing their activity and consequently the release of heat through microbial metabolism (Doublet et al., 2011). This indicates that the compost was in the stabilization phase (Ruggieri et al., 2012).

The Nt values obtained after 95 DASC in C1, C2, C3 and $\mathrm{C} 4$ were above the minimum of $0.5 \%$ BRASIL, 2009) (Table 5).

However, the highest Nt value was observed in C3. This can be attributed to the lowest temperature values during the first week of composting (Figure 1), which can reduce $\mathrm{N}$ losses by volatilization (Fukumoto et al., 2011).

The TOC values at 95 DASC in C1, C2, C3 and C4 were above the minimum value of $15 \%$ (BRASIL, 2009) (Table 5 ). The high concentration of total organic carbon in the

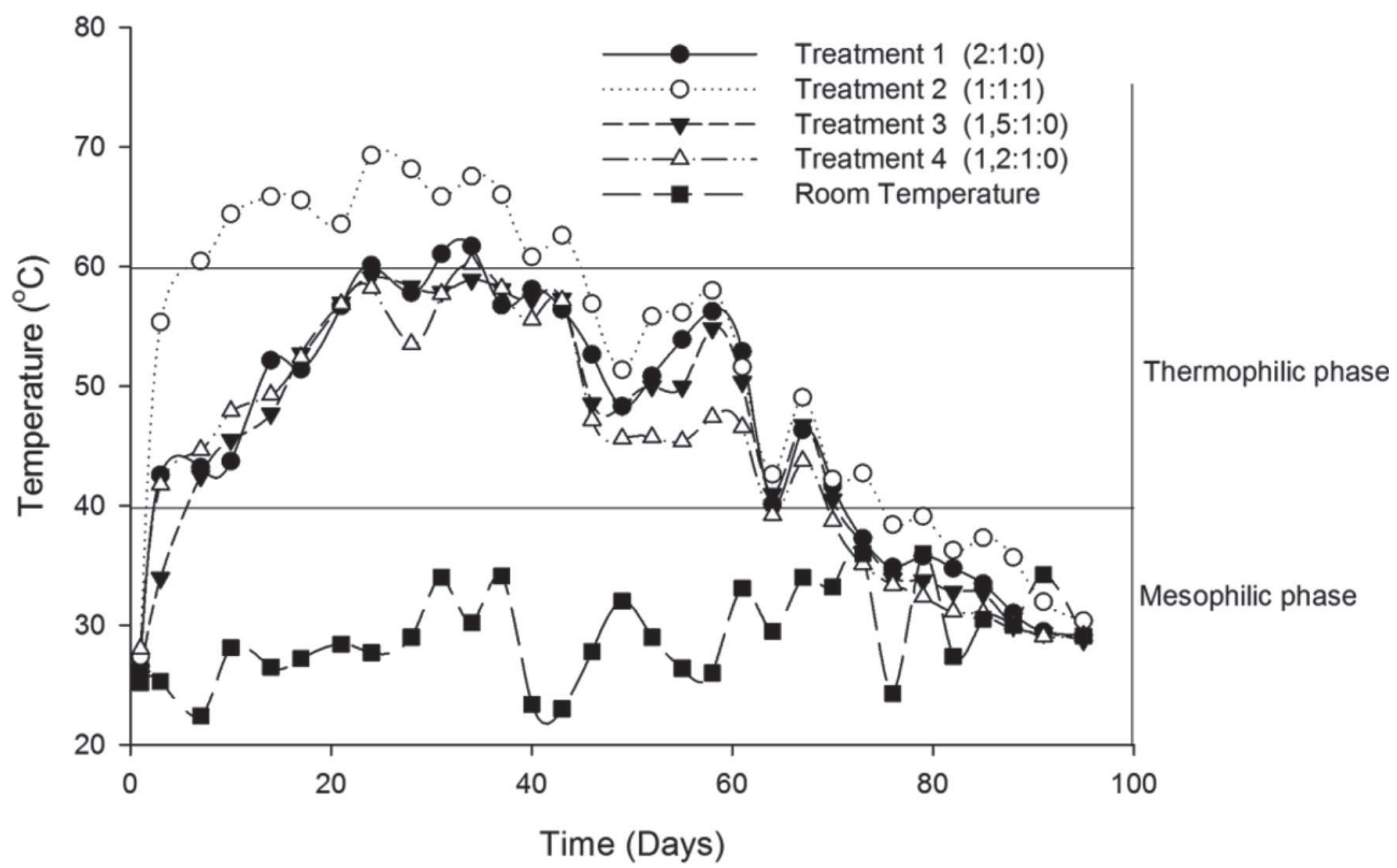

Figure 1: Average temperatures of the upper $(20 \mathrm{~cm}$ from the surface) and lower $(20 \mathrm{~cm}$ from the base) portions of the treatments during the composting period. 
organic composts can be attributed to the use of rice husk in the composting (Table 1). The RH can have 50\% cellulose, 30\% lignin and 20\% inorganic waste in its constitution (Fernandes, 2016).

The $\mathrm{C} / \mathrm{N}$ ratio of $\mathrm{C} 1, \mathrm{C} 2$ and $\mathrm{C} 3$ remained within the standard required by legislation (BRASIL, 2009) with values of 20.82, 15.9 and 20.81, respectively. Therefore, they may be considered matured organic fertilizers. However, C4 presented the highest $\mathrm{C} / \mathrm{N}$ ratio (29.96), due to the lower concentration of $\mathrm{N}(1.10 \%)$, which can be explained by the lower doses of FVW added to the compost mixture (Table 2). Furthermore, C4 and C1 presented the highest $\mathrm{pH}$ values (9.0 and 9.09, respectively), which may have stimulated the highest loss of $\mathrm{N}$ by volatilization, since this is enhanced in substrates with $\mathrm{pH}$ values above 7.5 (Bernal et al., 2009).

The $\mathrm{NH}_{4}^{+}-\mathrm{N}$ contents did not differ statistically between treatments $\mathrm{C} 1\left(62.53 \mathrm{mg} \mathrm{kg}^{-1}\right), \mathrm{C} 3\left(53.19 \mathrm{mg} \mathrm{kg}^{-1}\right)$ and $\mathrm{C} 4$ (39.19 $\mathrm{mg} \mathrm{kg}^{-1}$ ) (Table 5). However, C2 presented the highest concentrations of $\mathrm{NH}_{4}{ }^{+}-\mathrm{N}$ and $\mathrm{NO}_{3}{ }^{-} \mathrm{N}(179.19$ and $432.79 \mathrm{mg} \mathrm{kg}-1$, respectively). This may be related to the addition of PM, which has a high initial content of organic C (Table 1).

Zucconi \& Bertoldi (1987) assume values of more than $400 \mathrm{mg} \mathrm{kg}^{-1}$ of $\mathrm{NH}_{4}^{+}-\mathrm{N}$ as the limit for immature organic composts. The higher values in the concentrations of $\mathrm{NO}_{3}$ $-\mathrm{N}$ in comparison to $\mathrm{NH}_{4}^{+}-\mathrm{N}$ observed in all the composts indicate an intense nitrification of the organic $\mathrm{N}$ present in the compost wastes, which is first released as $\mathrm{NH}_{4}^{+}{ }^{+} \mathrm{N}$ and oxidized to $\mathrm{NO}_{2}^{-}-\mathrm{N}$ by the bacteria of the genus nitrobacter and, subsequently, to $\mathrm{N}-\mathrm{NO}_{3}$ by the nitrosomonas (Cantarella, 2007).

The highest values of Nmin were found in C1, C2 and C3 (Table 5). These values may be related to the highest doses of FVW added to the treatments. Guidoni et al. (2013) found comparable results in composting studies in bioreactors using waste similar to the one used in this study. On the other hand, the lowest values of Nmin were found in C4. This most likely happened because the lowest amounts of FVW were added to this treatment.

The highest contents of $\mathrm{P}$ and $\mathrm{K}$ were found in $\mathrm{C} 2$ (Table 5). This may possibly be related to the higher initial concentration of these nutrients present in PM, which was added to this treatment (Table 1). The legislation on organic fertilizers (BRASIL, 2009) does not provide the maximum or minimum values of $\mathrm{P}$ and $\mathrm{K}$. However, their contents must be declared in the product registration process (BRASIL, 2009).

The Ca contents were higher than the desired minimum (1\%) in $\mathrm{C} 1, \mathrm{C} 2$ and $\mathrm{C} 3$ (Table 5). Ca values below the required minimum were only found in $\mathrm{C} 4$. This may be because the lowest amount of FVW was added to this compost (Table 2), but also because of the low concentration of $\mathrm{Ca}$ in the other wastes (Table 1). All of the organic composts showed higher Fe content than the minimum value $(0.2 \%)$. Only C2 presented Mn content higher than the minimum required by legislation (BRASIL, 2009).

$\mathrm{C} 2$ was the only organic compost that exhibited a CEC/ $\mathrm{C}$ ratio higher than the minimum value $(\mathrm{CEC} / \mathrm{C}>20)$ (BRASIL, 2009) (Table 5). In addition, $C 2$ presented the highest EC values. The high nutrient contents may have been caused by the application of PM to the compost mixture, since it had high initial contents of $\mathrm{Ca}, \mathrm{Mg}, \mathrm{Na}, \mathrm{K}$ and $\mathrm{P}$ (Table 1). Additionally, the high CEC values may be related to the increase in TOC content, due to the initial composition of the PM, which makes it possible to increase the functional exchange groups (Sartor et al., 2012).

The CEC/C ratio may even be more appropriate than the $\mathrm{C} / \mathrm{N}$ ratio in indicating the decomposition stage of organic waste, because the $\mathrm{C} / \mathrm{N}$ ratio can be seriously affected by the presence of ammoniacal N (SánchezMonedero et al., 2010), which may overestimate the concentration of $\mathrm{N}$, resulting in a lower $\mathrm{C} / \mathrm{N}$ ratio than it actually is.

The $\mathrm{pH}$ values obtained in the four organic composts (Table 5) were higher than the $\mathrm{pH}$ established by legislation (6.0) (BRASIL, 2009). Values of $\mathrm{pH}$ close to or greater than 6.0 are typically found in organic composts. This happens in the final stage of the composting process with the degradation of organic acids that are produced in the initial stage of decomposition of carbonaceous materials. A group of microorganisms capable of using these organic acids decomposes them; excreting basic substances that raise the $\mathrm{pH}$ of the final compost (Corrêa et al., 2012).

$\mathrm{C} 2$ presented the lowest moisture value at 95 DASC. It is the only compost with a value lower than the maximum limit (50\% of moisture) established by legislation (BRASIL, 2009). This happened because of the higher loss of water by evaporation, due to the increased temperature during the composting process (Figure 1). This gain in temperature may be related to increased activity of the microbial population stimulated by the application of PM to the mixture during the preparation of the treatment (Wang et al., 2012).

Experiment 2: The $\mathrm{NH}_{4}^{+}-\mathrm{N}$ content in all the treatments increased from the first day to 14 days after incubation (DAI), especially in the 40\% AP + 60\% C2 (77 $\mathrm{mg} \mathrm{NH}_{4}{ }^{+}-\mathrm{N} \mathrm{kg}^{-1}$ ) treatment (Figure 2a).

At 28 and 56 DAI, the highest contents of $\mathrm{NH}_{4}{ }^{+} \mathrm{N}$ (56 and $45.33 \mathrm{mg} \mathrm{NH}_{4}^{+}-\mathrm{N} \mathrm{kg}^{-1}$, respectively) were found in the $70 \% \mathrm{AP}+30 \% \mathrm{C} 2$ treatment. At $112 \mathrm{DAI}$, the highest $\mathrm{NH}_{4}{ }^{+}-\mathrm{N}$ content was found in the $60 \% \mathrm{AP}+40 \%$ $\mathrm{C} 2$ treatment. On the other hand, at 14 and $112 \mathrm{DAI}$, the lowest $\mathrm{NH}_{4}{ }^{+}-\mathrm{N}$ content was found in the $40 \% \mathrm{AP}+60 \%$ 
CRH treatment. At 56 DAI, the $20 \% \mathrm{AP}+80 \% \mathrm{C} 2$ treatment presented the lowest $\mathrm{N}_{-} \mathrm{NH}_{4}{ }^{+}$content. The N$\mathrm{NO}_{3}{ }^{-}$content increased up to $20 \mathrm{DAI}$ in all the treatments and stabilized after 112 DAI (Figure 2b). At 7 and 14 DAI, the highest $\mathrm{NO}_{3}^{-}-\mathrm{N}$ contents were found in the $50 \%$ $\mathrm{AP}+50 \% \mathrm{C} 2$ and $60 \% \mathrm{AP}+40 \% \mathrm{C} 2$ treatments (Figure 2 b). The lowest $\mathrm{NO}_{3}^{-}-\mathrm{N}$ contents were found in the $40 \%$ $\mathrm{AP}+60 \% \mathrm{CRH}$ treatment at all the collection times.

The mineral $\mathrm{N}$ content in all the treatments increased up to 20 DAI (Figure 2c). Thereafter, the stabilization of mineral $\mathrm{N}$ content was observed in all the treatments up to 112 DAI. The highest values of mineral $\mathrm{N}$ at 7 and 14 DAI were found in the $50 \% \mathrm{AP}+50 \% \mathrm{C} 2$ and $60 \% \mathrm{AP}+$ $40 \% \mathrm{C} 2$ treatments, followed in decreasing order by the $30 \% \mathrm{AP}+70 \% \mathrm{C} 2,40 \% \mathrm{AP}+60 \% \mathrm{C} 2,70 \% \mathrm{AP}+30 \% \mathrm{C} 2$, $20 \% \mathrm{AP}+80 \% \mathrm{C} 2,80 \% \mathrm{AP}+20 \% \mathrm{C} 2$. The $40 \mathrm{AP}+60 \%$ $\mathrm{CRH}$ treatment had the lowest mineral $\mathrm{N}$ values at all sampling times.
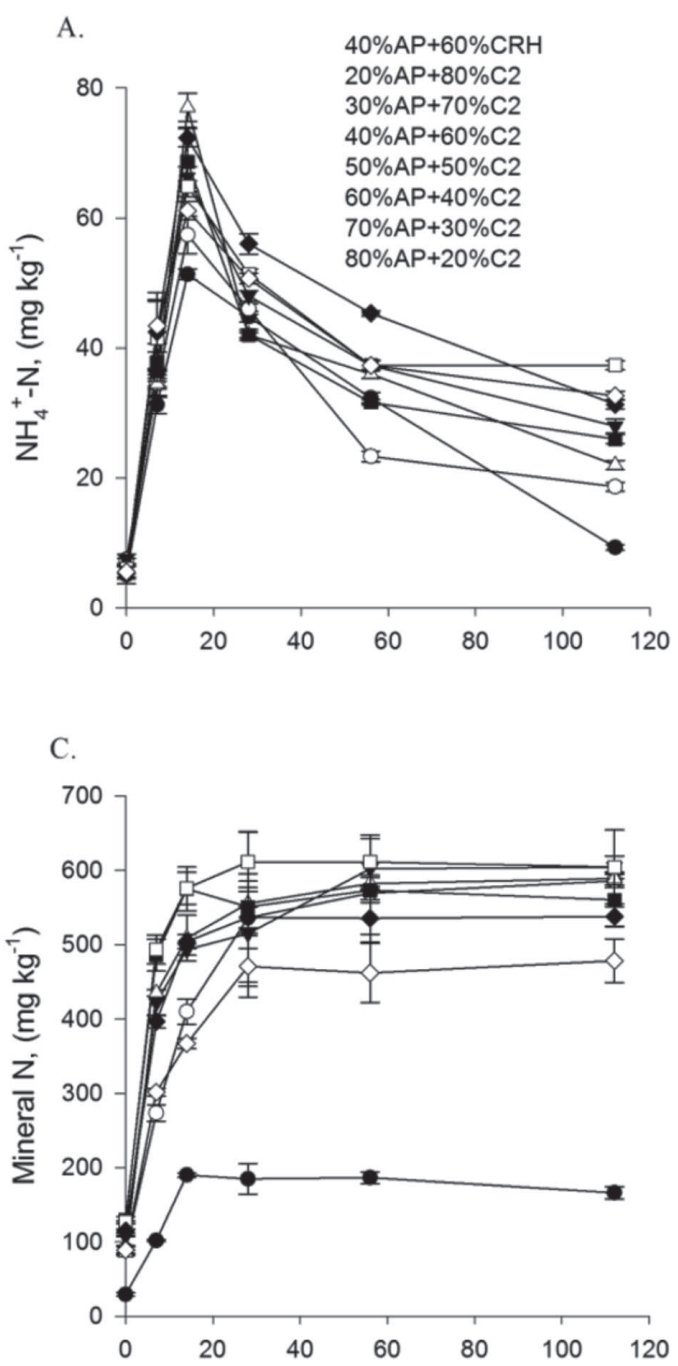

At $28 \mathrm{DAI}$, the $60 \% \mathrm{AP}+40 \% \mathrm{C} 2$ treatment had the largest amount of mineral $\mathrm{N}\left(611.33 \mathrm{mg} \mathrm{kg}^{-1}\right)$, followed by the $30 \% \mathrm{AP}+70 \% \mathrm{C} 2,40 \% \mathrm{AP}+60 \% \mathrm{C} 2,50 \% \mathrm{AP}+50 \%$ $\mathrm{C} 2$ and $70 \% \mathrm{AP}+30 \% \mathrm{C} 2$, which exhibit mineral $\mathrm{N}$ content ranging from 493.26 to $574.93 \mathrm{mg} \mathrm{kg}^{-1}$. At 56 and $112 \mathrm{DAI}$, the mineral $\mathrm{N}$ values were stabilized, especially in the $60 \%$ $\mathrm{AP}+40 \% \mathrm{C} 2$ treatment, which presented the highest value at all the evaluated times.

The high $\mathrm{NH}_{4}{ }^{+} \mathrm{N}$ values found in all the treatments at 20 DAI may be related to the higher initial concentration of $\mathrm{NH}_{4}{ }^{+} \mathrm{N}$ present in organic compost $\mathrm{C} 2$ (Table 5), used in the preparation of the treatments. This result is consistent with values found by Silva et al. (2009), who evaluated maturation parameters for different organic composts.

The rapid increase in $\mathrm{NO}_{3}^{-}-\mathrm{N}$ content at $20 \mathrm{DAI}$ can be attributed to the high initial concentration of $\mathrm{NH}_{4}{ }^{+} \mathrm{N}$ present in $\mathrm{C} 2$ (Table 5), which is oxidized to $\mathrm{NO}_{2}^{-}-\mathrm{N}$ by

B.

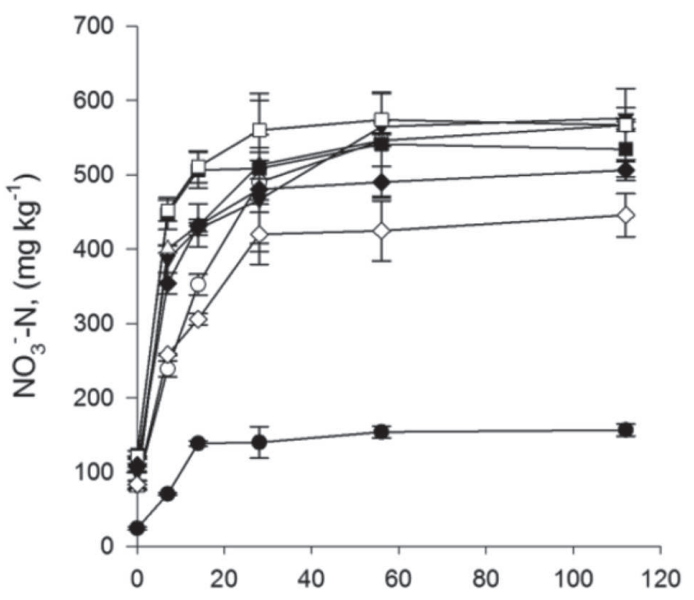

D.

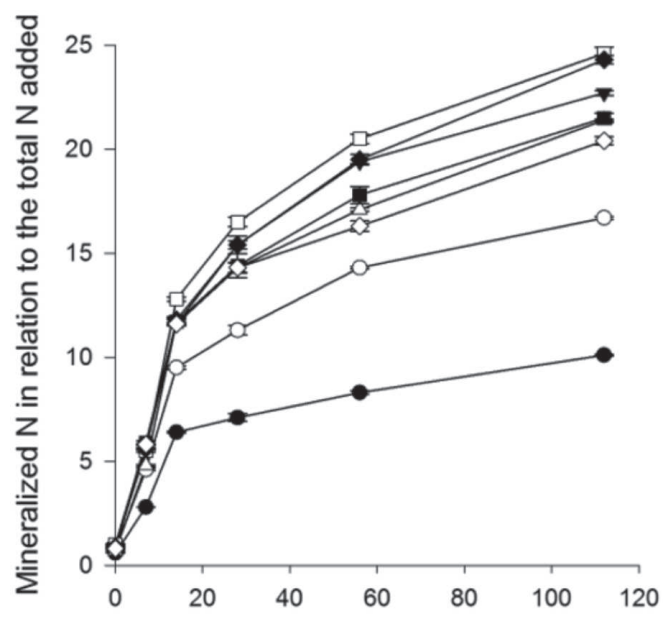

Days after incubation

Figure 2: Contents of $\mathrm{NH}_{4}^{+}-\mathrm{N}(\mathrm{A}), \mathrm{NO}_{3}-\mathrm{N}(\mathrm{B})$, mineral $\mathrm{N}(\mathrm{C})$, and mineralized $\mathrm{N}$ in relation to the total $\mathrm{N}$ added (D) in eight substrates over 112 days after incubation. Vertical bars indicate the standard error. 
bacteria of the genus nitrobacter and subsequently to

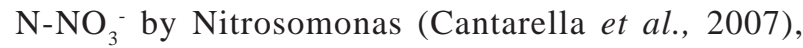
increasing its concentration in the substrate. The lowest $\mathrm{NO}_{3}^{-}-\mathrm{N}$ contents in the $40 \% \mathrm{AP}+60 \% \mathrm{CRH}$ treatment can be attributed to the low release rate of $\mathrm{Nt}$ contained in the treatment (Table 4).

The highest values of mineralized $\mathrm{N}(\% \mathrm{Nmin})$ in relation to total $\mathrm{N}$ over $112 \mathrm{DAI}$ were found in the $60 \% \mathrm{AP}$ $+40 \% \mathrm{C} 2$ and $70 \% \mathrm{AP}+30 \% \mathrm{C} 2$ treatments (Figure 2d). The $60 \% \mathrm{AP}+40 \% \mathrm{CRH}$ treatment showed the lowest mineralized $\mathrm{N}$ value in relation to the total $\mathrm{N}$ added at all collection times. The highest mineralized $\mathrm{N}$ value found in relation to the total $\mathrm{N}$ added may be associated to the lower $\mathrm{C} / \mathrm{N}$ ratio present in the treatments (Table 4 ), enabling the predominance of the $\mathrm{N}$ mineralization process rather than the immobilization process (Oliveira et al., 2012).

\section{CONCLUSIONS}

Composts 1, 3 and 4 presented values of total organic carbon, $\mathrm{N}$ and $\mathrm{pH}$ within the parameters required by legislation. However, they do not present characteristics of mature compost to be used as fertilizer in crops.

Compost 2, which consisted of a 1:1:1 ratio of the mixture of FVW, RH and PM, obtained the best performance among the composts. It exhibited the required values for the following chemical maturation and quality parameters: $\mathrm{C} / \mathrm{N}$ ratio, TOC, $\mathrm{N}, \mathrm{P}, \mathrm{K}, \mathrm{Ca}, \mathrm{Fe}, \mathrm{Mn}, \mathrm{CEC} / \mathrm{C}, \mathrm{pH}$ and moisture $\%$. Therefore, it can be used as organic fertilizer.

The use of doses of organic compost in the substrate composition promoted the mineralization of $\mathrm{N}$ in comparison to the control treatment, especially the $60 \%$ $\mathrm{AP}+40 \% \mathrm{C} 2$ treatment, which had the highest mineral $\mathrm{N}$ content at all collection times, as well as the highest mineralized $\mathrm{N}$ content in relation to the total added, providing $25 \%$ of the total $\mathrm{N}$ of the treatment at 112 days after incubation.

\section{REFERENCES}

ABRAS - Associação Brasileira de Supermercados (2015) Fórum trás dimensão global à prevenção de perdas . Disponível em: <http://www.abrasnet.com.br/economia-e-pesquisa/perdas/pesquisa-2015/>. Acessado em: 10 de dezembro de 2016.

Andreoli CV (2011) Resíduos sólidos do saneamento: processamento, reciclagem e disposição final. Rio de Janeiro, RiMa / ABES. 565p.

Bernal MP, Alburquerque JA \& Moral R (2009) Composting of animal manures and chemical criteria for compost maturity assessment. Bioresource Technology, 37:5444-5453.

BRASIL (2009) Instrução Normativa nR" 25, de 23 de julho de 2009. Normas sobre as especificações e as garantias, as tolerâncias, o registro, a embalagem e a rotulagem dos fertilizantes orgânicos simples, mistos, compostos, organominerais e biofertilizantes destinados à agricultura. DOU, 28/07/2009, Seção 1, p. 20.
Bueno P, Tapias R, López F \& Díaz MJ (2008) Optimizing composting parameters for nitrogen conservation in composting. Bioresource Technology, 99:5069-5077.

Cantarella H (2007) Nitrogênio. In: Novais RF, Alvarez V VH, Barros NF de, Fontes RL, Cantarutti RB \& Neves JCL (Eds.) Fertilidade do Solo. Viçosa, Sociedade Brasileira de Ciência do Solo. p.375-470.

Corrêa ÉK, Ulguima RR, Corrêa LB, Castilhos DD, Bianchi I, GilTurnes C \& Lucia Jr T (2012) Addition of Bacillus sp. inoculums in bedding for swine on a pilot scale: Effect on microbial population and bedding temperature. Bioresource Technology, 121:127-130.

Costa MS, Costa LAM, Decarli LD, Pelá A, Silva CJ, Matter UF \& Olibone D (2009) Compostagem de resíduos sólidos de frigorífico. Revista Brasileira de Engenharia Agrícola e Ambiental, 13:361-379.

Dores PR, Landgraf MD \& Rezende MDO (2013) Processo de estabilização de resíduos orgânicos: vermicompostagem versus compostagem. Química Nova, 36:640-645.

Doublet CJ, Poitrenaud FM \& Houot S (2011) Influence of bulking agents on organic matter evolution during sewage sludge composting; consequences on compost organic matter stability and $\mathrm{N}$ availability. Bioresource Technology, 102:1298-1307.

Fernandes IJ (2016) Characterization of rice husk ash produced using different biomass combustion techniques for energy. Bioresource Technology, 165:351-359.

Ferreira DF (2008) SISVAR: Um programa para análises e ensino de estatística. Revista Symposium, 06:36-41.

Fukumoto Y, Suzuki K, Kuroda K, Waki M \& Yasuda T (2011) Effects of struvite formation and nitratation promotion on nitrogenous emissions such as $\mathrm{NH}_{3}, \mathrm{~N}_{2} \mathrm{O}$ and $\mathrm{NO}$ during swine manure composting. Bioresource Technology, 102:14681474.

Guidoni LLC, Bittencourt G, Marques RV, Corrêa LB \& Corrêa EK (2013) Compostagem domiciliar: implantação e avaliação do processo. Revista Tecnológica, 17:44-51.

Hubbe MA, Nazhad M \& Sánchez C (2010) Composting as a way to convert cellulosic biomass and organic waste into high-value soil amendments. BioResources, 05:2808-2854.

Kiehl EJ (2010) Novo Fertilizantes Orgânicos. Piracicaba, Agronômica Ceres. 247p.

Morais ERC \& Maia CE (2013) Crescimento da parte aérea e raiz do meloeiro adubado com fertilizante orgânico. Revista Ciência Agronômica, 44:505-511.

Oliveira LB, Accioly AMA, Menezes RSC, Alves RN, Barbosa FS \& Santos CLR (2012) Parâmetros indicadores do potencial de mineralização do nitrogênio de compostos orgânicos. Idesia, 30:65-73.

Ruggieri L, Gea T, Artola A \& Sanchez A (2012) A study on air filled porosity evolution in sludge composting. International Journal of Environment and Waste Management, 09:56-58.

Sánchez-Monedero MA, Roig A, Cegerra J \& Bernal MP (2010) Nitrogen transformation during organic waste composting by the Rutgers system and its effects on $\mathrm{pH}$, EC and maturity of the composting mixtures. Bioresource technology, 78:301308 .

Sartor LR, Assmann AL, Assmann TS, Bigolin PE, Miyazawa M \& Carvalho PCF (2012) Effect of swine residue rates on corn, common bean, soybean and wheat yield. Revista Brasileira de Ciência do Solo, 36:661-669. 
Silva FA de Melo, Villas Boas RL \& Silva RB (2009) Parâmetros de maturação para diferentes compostos orgânicos. Revista Brasileira de Agroecologia, 04:67-78.

Sivakumar K, Kumar VRS, Jagatheesan PNR, Viswanathan K \& Chandrasekaran D (2008) Seasonal variations in composting process of dead poultry birds. Bioresource Technology, 99:37083713 .

Souza MSB, Vieira LM, Silva MJ \& Lima A (2011) Caracterização Nutricional e Compostos Antioxidantes em Resíduos de Polpas de Frutas Tropicais. Ciência e Agrotecnologia, 35:554-559.

Tedesco MJ, Gianello C, Bissani CA, Bohnen H \& wolkweiss SJ (1995) Análises de solo, plantas e outros materiais. $2^{a}$ ed. Porto Alegre, Universidade Federal do Rio Grande do Sul. 174p. (Boletim Técnico, 5)
Wang X, Yang G, Feng Y, Ren G \& Han X (2012) Optimizing feeding composition and carbon-nitrogen ratios for improved methane yield during anaerobic co-digestion of dairy, chicken manure and wheat straw. Bioresource Technology, 120:78-83.

Yang F (2013) Effect of bulking agents onmaturity and gaseous emissions during kitchen waste composting. Chemosphere, 93:1393-1399.

Zibilske LM \& Materon LA (2015) Biochemical properties of decomposition cotton and corn stem and root resídues. Soil Science Society of America Journal, 69:378-386.

Zucconi F \& Bertoldi M (1987) Composts specifications for the production and characterizationof composts from municipal solid waste. In: Bertoldi M, Ferranti MP, L2 Hermite MP \& Zucconi F (Eds.) Compost: production, quality and use. London, Elsevier Applied Science. p.30-50. 